Ukrayinskoyi RSR v 1963 roci. Statistichnij shorichnik, Derzhavne statistichne vidavnictvo, Kyiv (1964), S. 61; Narodne gospodarstvo Ukrayinskoyi RSR v 1964 roci. Statistichnij shorichnik, Derzhavne statistichne vidavnictvo, Kyiv (1965), 54.

33. Spravka o sostoyanii obshestvennogo pitaniya i bytovogo obsluzhivaniya $\mathrm{v}$ sovhozah Odesskogo vinodelcheskogo tresta. (Sostavlena upravlyayushim trestom F. Manzienko). CDAVO Ukrayini. F. 2605, op. 8, Spr. 3098.

34. Spravka o hode vypolnenii reshenij HH sezda KPSS profsoyuznymi organizaciyami Harkovskoj oblasti. CDAVO Ukrayini. F. 2605, op. 8, spr. 2022.

35. Srednemesyachnaya zarabotnaya plata po ekonomike Ukrainy. URL: https://i.factor.ua/info/pension/avg-ua/

36. Stalin, J. V. (1952). Ekonomicheskie problemy socializma v SSSR, Gospolitizdat, Moscow.

37. Ustav professionalnyh soyuzov SSSR (1952), Utverzhdyon X sezdom profsoyuzov SSSR (19-27 aprelya 1949 g.), Profizda.

УДК 622.276(477.75)»1954»:33.012.8-045.45

\title{
НАФТОГАЗОВИЙ КОМПЛЕКС КРИМУ ТА ІНТЕГРАЦІЯ ПІВОСТРОВА В ЕКОНОМІЧНУ СИСТЕМУ УРСР У 1954 Р.
}

\section{Сацький Павло}

У статті на основі архівних матеріалів здійснено дослідження інституиійного забезпечення $і$ основних етапів та особливостей розвитку нафтогазового комплексу Кримської області у період після Другої світової війни та у 1954 р. Метою статті є комплексний аналіз політики СРСР у формуванні інституцій, які здійснювали освоєння родовищ нафти $i$ газу в Криму та основних напрямів їх діяльності, а також змін у підходах до подальшого розвитку нафтогазового комплексу Кримського півострова після його включення до складу УРСР 1954 . Автором у процесі дослідження застосовано як проблемно-хронологічний метод, так і методику системного аналізу. У результаті здійсненого дослідження автором встановлено, що структура інституиійного забезпечення нафтогазового комплексу Кримської області у період ї̈ перебування в складі РСФРР не давала змоги для ефективного освоєння ресурсів півострова. Розвиток нафтогазової галузі в Криму для Ради Міністрів РСФРР і профільних інституиій Союзного Уряду не мав вагомого значення. Також, розвідку перспективних нафтових $i$ газових родовищ у Криму було зосереджено на Керченському півострові. Передача Кримської області до складу УРСР 1954 р. закладає можливості для зміни інституиійної бази розвитку нафтогазового комплексу в Криму, 
а також до постановки питання про освоєння перспективних нафтогазоносних площу на півострові.

Ключові слова: геофізичні дослідження в Криму, Периий Секретар Кримського обкому КПУ Д. Полянський, Перший Секретар ЦК КПУ А. Кириченко, трест «Кримнафтогазрозвідка», об 'єднання «Укрнафта».

Кримський півострів в історії України завжди відігравав особливу політичну й економічну роль. 3 огляду на події останніх років у Криму особливої актуальності набуває проблематика соціально-економічного розвитку півострова у ХX ст. Фонди українських архівів доволі широко висвітлюють процес соціально-економічної інтеграції Криму із Україною, який прискорювався i поглиблювався iз розвитком економіки УРСР, особливо із активним економічним розвитком південних областей України у період після Другої світової війни. Одним із аспектів соціально-економічної інтеграції Криму із Україною було питання розвитку нафтогазової промисловості на півострові. Ця галузь промисловості Криму не мала стратегічного значення для СРСР, оскільки на півострові обсяги розвідки і видобутку нафти і газу були незначними у масштабах видобутку в Радянському Союзі [1]. Отже, нафтогазовий комплекс Криму мав локальний характер і був цілковито залежний від намірів керівництва загальносоюзного центрального органу управління галуззю. У свою чергу, не зважаючи на доволі глибокий рівень соціально-економічної інтегрованості між УРСР і Кримом іще до передачі півострова до складу України у 1954 р., український республіканський нафтогазовий комплекс не мав впливу на розвиток кримського.

Проблематика розвитку нафтогазового комплексу Криму не знайшла належного відображення в науковій літературі, очевидно із-за незначної його частки у нафтогазовій промисловості Радянського Союзу. Проте, доволі цінними є дослідження і аналіз загальних тенденцій розвитку цієї галузі в СРСР у період після Другої світової війни. Цю проблему в своїх працях розробляли такі автори як В. Карпов [2], Е. Хромов [14], М. Славкіна[11; 12$].$ Зокрема, звертається увага на те, що в політиці СРСР щодо розвитку нафтогазового комплексу найбільше уваги приділялося розвідуванню і видобутку великих обсягів ресурсів та створенню потужної мережі їх транспортування. Основні цілі такої політики були очевидними, і полягали вони у забезпеченні потужного експортного потенціалу СРСР, що, у свою чергу обумовило залежність економіки Радянського Союзу від кон'юнктури на світовому нафтогазовому ринку, енергозатратність економіки та іiі сировинну спрямованість. За такого спрямування політики СРСР щодо розвитку нафтогазового комплексу країни відповідна галузь в Криму не мала перспективи розвитку через незначні обсяги розвідки і видобутку, тому їі розвиток був можливий за умови забезпечення їі потреб на регіональному рівні. 
Метою статті є дослідження на матеріалах українських архівів значення процесу соціально-економічної інтеграції Криму із УРСР для зміни умов розвитку нафтогазового комплексу Кримської області.

Для аналізу стану справ у нафтогазовій галузі Криму до його включення у склад УРСР слід, у першу чергу, звернути увагу на інституційне забезпечення іiі розвитку на півострові. Централізацію нафтогазової розвідки в Криму було здійснено 1933 р. зі створенням тресту «Кримгазнафта»у у підпорядкуванні Народного Комісаріату нафтової промисловості СРСР. Після завершення Другої світової війни у 1945 р. трест розгорнув діяльність по розвідуванню й освоєнню нафтових родовищ у Криму, проте, із новими кадрами i на старому обладнанні, завезеному із Краснодарського краю. У 1946 р. трест отримав назву «Кримнафтогазрозвідка» i перебував у підпорядкуванні Міністерства нафтової промисловості СРСР, а 1948 р. трест було перепідпорядковано Міністерству геології СРСР та перейменовано на «Кримнафтогеологія». Того ж року на базі відкритого Керлеутського нафтового родовища було утворено Мошкарівський Укрупнений нафтопромисел, який передано у підпорядкування Об'єднання «Краснодарнафта» Міністерства нафтової промисловості СРСР [13, 37]. У цьому моменті із підпорядкуванням самого тресту Міністерству геології СРСР, а окремого промислу Міністерству нафтової промисловості СРСР слід звернути увагу на підхід керівництва СРСР до розробки нафтових родовищ у Криму. Адже до Міністерства нафтової промислості, причому, нафтовому підприємству за межами Кримської області, було підпорядковано родовище, котре була можливість експлуатувати, а підприємство по розвідці, яке мало громіздку структуру і потребувало капітальних вкладень і структурної перебудови, залишалося у підпорядкуванні Міністерства геології СРСР. Отже, на 1948 р. особливої перспективи у розвитку нафтової промислості в Криму, яка полягала у системності нафторозвідувальної діяльності, керівництво СРСР не вбачало, більш актуальним був видобуток ресурсів екстенсивним шляхом. У цій ситуації слід зауважити, що подібний підхід до розвитку нафтогазового комплексу в Криму було застосовано у зв'язку із тим, що видобуток нафти на півострові на той період не давав змоги покривати витрати на розвідувальні роботи.

Проте, вже 20 червня 1952 р. постановою Ради Міністрів СРСР трест «Кримнафтогеологія» було підпорядковано Міністерству нафтової промисловості СРСР. На підставі постанови Ради Міністрів СРСР від 13 жовтня 1952 р. трест реорганізовано шляхом передачі йому ряду підприємств та організацій, і він отримав назву «Кримнафтогазрозвідка» $[13,36]$. Отже, на 1952 р. керівництво СРСР вже виявляло інтерес до розвитку нафтогазового комплексу в Криму. У результаті реорганізації в структурі тресту перебували ряд виробничих організацій: Мошкарівська контора розвідувального буріння, Приморська контора розвідувального буріння, Джанкойська нафторозвідка i геолого-пошукова контора. У структурі тресту перебував також ряд 
допоміжних і підсобних підприємств $[13,37]$. Таким чином, трест «Кримнафтогазрозвідка» концентрував у своїй структурі усі підприємства, якими здійснювалась нафтогазорозвідувальна діяльність на території півострова. Отже, структура підприємства мала регіональний характер. Можливо, це було зумовлено перспективами соціально-економічного розвитку Криму, який намагалися стимулювати вже в 1951 р. Рада Міністрів УРСР і ЦК КП(б)У. 3 метою стимулювання соціально-економічного розвитку Криму керівні інституції УРСР за зверненнями начальника «Укрводбуду» А. Бочкіна і начальника Сталінської залізниці К. Коломійцева, мотивували керівництво СРСР розвивати транспортне сполучення УРСР із Кримом [7, 73-74].

Щодо власне стану розвитку нафтогазової промисловості в Криму у період перебування півострова у складі РРФСР слід звернути увагу на дані, які містилися у рішенні геолого-технічної наради, яка пройшла після включення Криму до складу УРСР 17-20 березня 1954 р. у місті Феодосія. Ця нарада мала виробничий характер i нею було прийнято рекомендаційне рішення щодо подальшого розвитку нафтогазової промисловості на півострові. У рішенні цієї наради, зокрема, викладено стан справ у нафтогазовій промисловості Кримського півострова. Зокрема, відзначено, що на предмет розвідки в Криму на момент проведення геолого-технічної наради було вивчено 50 ділянок і підготовлено до розвідки 23 на Керченському півострові та 4 - в інших районах Криму. На цих ділянках пробурили 762 свердловини. Також гравіметричною і магнітною зйомками було покрито увесь Керченський півострів та Степовий Крим, а сейсмічні дослідження було проведено в

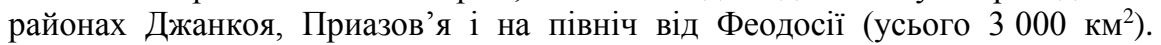
Для глибокої сейсмічної розвідки було рекомендовано Джанкойську і Гончарівську (на північ від Феодосії) ділянки. Зазначалося також, що від 1946 по 1953 рр. в Криму у розвідочному бурінні перебувало 17 ділянок, із них 15 на території Керченського півострова і дві - у степу та передгірській частині Криму. Усього у період після Другої світової війни пробурили 202 свердловини, із яких 94,8 \% на Керченському півострові і 5,2 \% в інших районах Криму. Із цих 202 свердловин: 40 було ліквідовано через технічні причини, 44 - дали нафту і 6 - газ [8, 67-68]. Проте у висновку геологотехнічної наради стверджувалося, що перспективи розвитку нафтогазової галузі в Криму лишалися незрозумілими, через те що більшість розвідувальних робіт здійснювалася на території Керченського півострова $[8,66]$. Отже, впродовж усього періоду розвитку нафтогазової промисловості в Криму роботи здійснювалися переважно на Керченському півострові, що свідчить про екстенсивний характер розвитку цієї галузі на півострові.

У 1954 р. Міністерство нафтової промисловості СРСР різко скорочує обсяги нафтової розвідки і промислової розробки нафтогазових родовищ на Керченському півострові в Криму. У зв'язку із цим Перший Секретар Кримського обкому КПУ Д. Полянський звернувся до Заступника Голови 
Ради Міністрів СРСР Л. Кагановича із листом, у якому просив зобов'язати Міністерство нафтової промисловості СРСР переглянути рішення про скорочення геологорозвідувальних робіт на Керченському півострові, а також різко збільшити обсяги геофізичних досліджень в Криму. Метою збільшення геофізичних досліджень в Криму, як мотивував у своєму зверненні Д. Полянський, було забезпечення підготовки нових перспективних структур для промислової розвідки покладів газу і нафти $[5,104]$. Отже, Перший Секретар Кримського обкому КПУ Д. Полянський мав повноваження звертатися зі зверненнями щодо окремих проблем безпосередньо до членів Ради Міністрів СРСР по окремих питаннях. Важливо звернути увагу на принциповий факт, адже Д. Полянський звернувся до Заступника Голови Ради Міністрів СРСР Л. Кагановича, який курував у Союзному уряді транспортну галузь СРСР. Тобто, Л. Каганович до нафтової промисловості прямого відношення не мав. Звернення до нього могло бути мотивованим міжособистісними відносинами у вищому ешелоні номенклатури Радянського Союзу. Також, слід звернути увагу, що Д. Полянський звернувся до Ради Міністрів СРСР особисто, хоча був партійним функціонером на чолі області УРСР по партійній лінії він підпорядковувався ЦК КПУ.

Варто у даному випадку відзначити особливість адміністрування соціально-економічної системи Кримської області із її включенням до УРСР. Фактично, партійна організація в Криму була головною адмініструючою інституцією в області. Виконавчі органи Кримської області, зокрема, у питанні відновлення Севастополя, брали участь у вирішенні питань в органах Ради Міністрів СРСР за допомогою Постійного Представництва УРСР у Москві [10,151]. Причому, доцільність участі представників органів виконавчої влади Кримської області в обговоренні питання відновлення Севастополя ініціювалася представником Ради Міністрів УРСР Г. Єсіпенком й узгоджувалася з Першим Секретарем ЦК КПУ А. І. Кириченком. Тобто, представники органів виконавчої влади Кримської області в органах виконавчої влади СРСР мали змогу відстоювати свою позицію за підтримки партійних органів УРСР.

Зовсім інакшим було становище партійних органів УРСР і Кримської області. Партійні органи мали забезпечувати відповідну суспільно-політичну атмосферу в області за умов іiї інтеграції до УРСР. Також партійні органи в умовах передачі Криму зі складу РРФСР до складу УРСР були єдиними, які зберігали свої адміністративні якості не лише де-юре, на підставі Статуту КПРС і Конституції СРСР, а також і де-факто, оскільки в результаті передачі Криму до іншої адміністративної системи виконавчі органи області втратили свої структурні функціональні якості. Для розуміння ситуації щодо стану функціональних якостей органів виконавчої влади в Кримській області у період iї перебування в РРФСР слід звернути увагу на те, що соціальноекономічний розвиток області відбувався завдяки ініціативній підтримці органів виконавчої влади області й окремих підприємств зі сторони Ради 
Міністрів РРФСР, а також зі сторони «зацікавлених» загальносоюзних міністерств, котрі сприяли соціально-економічному розвитку Криму. У цьому випадку мова могла йти про будівництво відомчих закладів для лікування та відпочинку, підприємств сільськогосподарського виробництва тощо. Тому можливості виконавчих органів у Криму щодо забезпечення соціально-економічного розвитку півострова перебували в залежності від ініціатив Ради Міністрів РРФСР і загальносоюзних міністерств. Із переходом Криму до іншої адміністративної системи органи виконавчої влади в області мали вибудовувати принципово нову систему відносин із виконавчими інституціями УРСР і з загальносоюзними інституціями. У цьому процесі ключову роль відігравали партійні структури, оскільки правляча КПРС мала особливий конституційний статусу в СРСР.

В умовах протистояння між урядовою і партійною вертикаллю в СРСР післясталінського періоду республіканські й регіональні організації правлячої партії мали особливі можливості, зокрема, для звернення до вищих органів виконавчої влади, адже мали найбільш представницький мандат за конституційним статусом правлячої партії. У Криму цей мандат був особливим в умовах фактичної передачі справ області від однією республіки СРСР до іншої. Зокрема, ставилися питання про передачу багатьох господарських об'єктів із балансу Ради Міністрів РРФСР і загальносоюзних інституцій на баланс інституцій Ради Міністрів УРСР [3, 71-72]. Завдання щодо державного плану розвитку народного господарства СРСР було представлено спільно Радою Міністрів РРФСР і Радою Міністрів УРСР, і затверджено Радою Міністрів СРСР розпорядженням від 3 травня 1954 р. Цим розпорядженням також було затверджено фонди стосовно державного плану забезпечення народного господарства СРСР на 1954 р., які передавалися Радою Міністрів РРФСР Раді Міністрів УРСР, у зв'язку із передачею Криму зі складу РРФСР до складу УРСР. Тому союзні, союзно-республіканські міністерства та відомства і Держплан СРСР мали внести відповідні поправки в план розвитку народного господарства на 1954 р. [4, 45]. Отже, передача завдань щодо розвитку господарства Криму за окремими об'єктами, а також фінансові й матеріальні фонди по них відбувалася на рівні Рад Міністрів РРФСР і УРСР і Ради Міністрів СРСР, а виконавчі органи Кримської області у цьому процесі виступали лише об'єктами. Натомість, Кримський обком КПУ мав повноцінний статус обласної партійної інституції, причому, в області, яка в процесі передачі від однієї республіки СРСР до іншої, мала особливий статус. Тому Перший Секретар Кримського обкому КПУ Д. Полянський за посадою мав особливий статус, який давав йому змогу оперативно, минаючи численні бюрократичні формальності радянської командно-адміністративної системи, вирішувати питання області.

У відповідь на звернення Д. Полянського апарат Ради Міністрів СРСР підготував проект рішення Бюро по металургії, паливній промисловості i геології, яким не було підтримано прохання Д. Полянського щодо 
збільшення обсягів геофізичних досліджень у Кримській області у зв'язку з низькою ефективністю капіталовкладень у пошуки газу і нафти на півострові. Також постановою Ради Міністрів СРСР 9 липня 1954 р. було передбачено скорочення бурових робіт у Кримській області. На 18 серпня 1954 р. було призначено засідання Бюро по металургії, паливній промисловості й геології при Раді Міністрів СРСР щодо питання, з яким звертався Д. Полянський на ім'я Заступника Голови Ради Міністрів СРСР Л. Кагановича. Представник УРСР при Раді Міністрів СРСР звертався до Голови Ради Міністрів УРСР і Першого Секретаря ЦК КПУ із питанням щодо їхньої позиції по питанню, яке було піднято перед Радою Міністрів СРСР Д. Полянським [5, 105]. Отже, Постпредство Ради Міністрів УРСР у Москві вважало за свій обов'язок відстежувати у вищих органах влади СРСР проблеми, які стосувалися республіки, навіть якщо вони порушувалися не центральними органами управління республіки.

Міністерство нафтової промисловості СРСР, як видно зі звернення Д. Полянського, виявило свою цілковиту байдужість щодо розвитку нафтогазової промисловості у Криму, адже було зацікавленим у збереженні фондів із бюджету СРСР за своїм відомством, із можливістю їх використання на інших підвідомчих йому об'єктах. Проте, до передачі Криму від РРФСР до УРСР Міністерство нафтової промисловості СРСР було змушене займатися питаннями промислової нафтової розвідки й освоєння родовищ на півострові. Лише із передачею Криму до УРСР у цього загальносоюзного міністерства виникає можливість позбутися такого проблемного активу як нафтогазовий комплекс Криму. Так, Міністерство нафтової промисловості СРСР не заперечувало проти передачі тресту «Кримнафтогазрозвідка» до структури об’єднання «Укрнафта», а також Кримської геофізичної контори тресту «Краснодарнафтогазгеофізика» до тресту «Укрнафтогеофізика» після вирішення Радою Міністрів СРСР питання про організаційну структуру цих інституцій. Це питання на 21 серпня 1954 р., коли Міністерство нафтової промисловості СРСР дало відповідь на запит Ради Міністрів УРСР і ЦК КПУ, перебувало на розгляді в Раді Міністрів СРСР [6, 120]. Тобто, загальносоюзне міністерство після скорочення робіт по розвідці нафтогазових родовищ у Криму не висловлювало заперечень щодо передачі кримських підприємств нафторозвідувального профілю республіканським підприємствам УРСР. Таким чином, є підстави вбачати у цьому прагнення позбутися малорентабельних об'єктів аби мати можливість спрямовувати фінансові фонди на інші об'єкти.

Для тресту «Кримнафтогазрозвідка» планом на 1953 р. було передбачено капіталовкладення у сумі 41850 тис. рублів. Виконано було із цього плану 37772 тис. рублів, тобто 90,3 \% і понад план освоєння коштів передбачено не було, на відміну від інших позицій по капітальних вкладеннях в Кримській області. Усього по Криму (без Севастополя) було на 1953 р. передбачено капіталовкладень у сумі 673631 тис. рублів, із них виконано 513926 тис. 
рублів або 76,3 \% і понад план освоєно по області 22357 тис. рублів. Тобто, по капіталовкладеннях у «Кримнафтогазрозвідка» відсоток виконання був вищий за середній по області. Проте, на цей трест планом передбачалося не найбільші по області капіталовкладення, так на Камишбурунський залізорудний комбінат було заплановано 76700 тис. рублів (виконано 40000 тис. рублів, тобто лише 52,2\%), на завод імені Войкова 87130 тис. рублів (виконано 52018 тис. рублів, 59,7 \%) [9, 37]. Тобто, трест «Кримнафтогазрозвідка» був доволі ефективним підприємством із організаційною структурою, яка давала змогу оперативно освоювати капіталовкладення. Проте, оскільки нафтогазова галузь Кримської області не мала пріоритетного значення для СРСР, іiі було без заперечень передано у республіканське відання УРСР.

Проте, у цей самий період у Раді Міністрів СРСР також перебувало на розгляді питання про збільшення в Криму обсягів геофізичних досліджень, яке було підняте Першим Секретарем Кримського обкому КПУ Д. Полянським і на 18 серпня його мало розглядати Бюро по металургії, паливній промисловості й геології при Раді Міністрів СРСР. Тобто, одночасно здійснювалися заходи щодо нафтогазового комплексу Криму як Першим Секретарем Кримського обкому КПУ Д. Полянським, так і Радою Міністрів УРСР. Заходи проодили паралельно і без взаємного узгодження, а, отже, на цьому етапі інтеграції Криму до складу УРСР можемо констатувати про певну неузгодженість позицій між керівництвом УРСР і Криму, зокрема, у питанні нафтогазового комплексу. Причому, Д. Полянський намагається зберегти фінансування геологорозвідувальних робіт у Криму через Міністерство нафтової промисловості СРСР, тобто, фактично, його позиція суперечила ініціативі Ради Міністрів УРСР і ЦК КПУ. У даному разі позицію Д. Полянського можна пояснити прагматичними розрахунками, оскільки загальносоюзне міністерство мало змогу залучати значно більші матеріальні ресурси, які надходили із бюджету СРСР, причому, спрямовувало їх на проекти відповідно до профілю цього міністерства. Можливості підприємств республіканського підпорядкування були значно меншими, ніж загальносоюзного міністерства, а для бюджету УРСР витрати на нафтогазовий комплекс були не профільними. Відповідно, передачу кримських підприємств нафтогазового комплексу Д. Полянський розглядав як загрозу зменшення фінансових надходжень на розвиток цих підприємств. Отже, на цьому прикладі бачимо як у процесі передачі Криму із РРФСР до складу України відбувається процес зняття загальносоюзним міністерством із себе відповідальності за малорентабельні активи та потреби здійснювати капіталовкладення у ї розвиток. Проте в УРСР у результаті передачі об'єктів у підпорядкування республіканських підприємств відбувається формування регіонального нафтогазового комплексу.

Після включення Криму до складу УРСР питання про розвиток нафтогазового комплексу на півострові постає в новому ракурсі. 3 метою перегляду підходів до нафтогазорозвідки в Криму 17-20 березня 1954 р. 
у Феодосії було проведено геолого-технічну нараду. Цією нарадою прийнято рішення «Про напрямки і головні задачі геологорозвідувальних і розвідувальних робіт на нафту і газ в Кримській області на 1954-1956 pр.». Висновки й рекомендації цієї наради було спрямовано у Відділ промисловості ЦК КПУ, у Відділ промисловості Кримського обкому КПУ, а також у Кримський філіал Академії наук СРСР. Із числа адресатів, кому спрямовувалися рекомендації за напрямами розробки нафтових і газових родовищ на Кримському півострові слід зробити висновок, що дана галузь у 1954 р. у Криму мало цікавила загальносоюзні органи, в тому числі й Міністерство нафтової провисловостіСРСР. Проте інтерес до розвитку нафтогазової галузі в Криму виявляли як Кримський обком КПУ, так і ЦК КПУ. Причому обидві владні інституції мали доволі значні можливості лобіювати забезпечення розвитку і виділення капіталовкладень у кримський нафтогазовий комплекс iз бюджету СРСР та УРСР. Таким чином, нафтогазовий комплекс вже у перший місяць після юридичного оформлення передачі Криму від РРФСР до УРСР активно за ініціативою його керівництва інтегрується до економічної системи УРСР.

Нарада дійшла висновку й рекомендувала за рахунок скорочення геологорозвідувальних робіт на Керченському півострові здійснювати розвідки в Степовому і Передгірному Криму. Таке переміщення розвідувальних робіт було рекомендоване для того, що визначитися із перспективами розвитку нафтогазової промисловості півострова [8, 67-68]. А усі геолого-пошукові роботи було рекомендовано розгорнути винятково на території степового і передгірного Криму з метою підготовки ділянок для розвідки мезозойських відкладень, а також третинних опадів в Індольському i Сиваському прогинах [8, 68 зв]. Нарадою було підготовано іще ряд рекомендацій, які передбачали перенесення розвідувальних і пошукових робіт в інші райони Криму, крім Керченського півострова. Усі ці рекомендації свідчили про нагальну необхідність зміни структури робіт у нафтогазовій галузі і неможливість здійснити ці зміни в рамках системи управління, у якій перебувало підприємство «Кримнафтогазрозвідка» до включення Криму в склад УРСР.

Отже, нафтогазовий комплекс Кримської області у період її перебування в складі РРФСР не мав перспективи розвитку в глобальній системі цієї галузі в СРСР. Тому на Кримському півострові здійснювалась розвідка й видобуток нафти і газу лише на Керченському півострові, оскільки саме у цьому регіоні за найменших вкладень можливо було отримувати найбільші результати. Вже на 1954 р. перспективи нафтогазової розвідки на Керченському півострові було вичерпано. У цей час відбувається скорочення за ініціативою Союзного Уряду обсягів нафтогазової розвідки в Криму. Із передачею Криму зі складу РРФСР до складу УРСР нафтогазовий комплекс Кримської області інтегрується в підприємство «Укрнафта», і у цей період постає питання про надання розвитку нафтогазового комплексу нового імпульсу. Слід 
відзначити, що оскільки керівництво УРСР на початку 1950-х рр. показало свою ефективність в реалізації масштабних проектів на території України і Криму порівняно із загальносоюзними міністерствами, то для керівництва СРСР було цілком логічним передати ініціативу щодо розвитку нафтогазового комплексу Криму ЦК КПУ і Раді Міністрів УРСР.

Подальші дослідження проблеми розвитку нафтогазового комплексу Криму у період після передачі півострова від РРФСР до УРСР відкривають можливість аналізу й розуміння мотивів прийняття керівництвом СРСР такого вагомого політичного рішення, яке було зумовлено потребою надання нових імпульсів соціально-економічному розвитку півострова.

\begin{abstract}
In the current article the research of the institutional support has been made as well as the study of the main periods and the peculiarities of the development of the oil and gas complex of the Crimea area in the period of the World War II and in 1954. The goal of the article is the complex analysis of the political system of USSR in the formation of institutions which carried out the exploration of oil and gas in the Crimea and the main areas of their activity as well as the changes in the approaches to the further development of oil and gas in the Crimea peninsula after its incorporation into Ukrainian SSR. In the process of analysis, the author used the problem-chronological method as well as the method of the systemic analysis. As the result of the research, the author has found out that the structure of the institutional support of oil and gas complex in the Crimea area in the period of its continuance as a part of Russian Soviet Federative Socialist Republic did not provide the effective development of the resources available in the peninsula. The development of the oil and gas field in the Crimea peninsula was not important for the council of ministers of Russian Soviet Federative Socialist Republic as well as for the specialized institutions of the Federal government. Moreover, the exploration of the promising oil and gas fields in the Crimea was focused on the Kerch peninsula. The transfer of the Crimea region from the USSR to Ukrainian SSR in 1954 created the possibilities for the changes in the institutional background of the development of oil and gas complex in the Crimea as well as opened up the question of development of the promising oil and gas areas in the peninsula.

Key words: geophysical surveys in the Crimea, First Secretary of the Crimean Regional Committee of the Communist Party of Ukrainian D. Polianskiy, First Secretary of the Central Committee of the Communist Party of Ukrainian A. Kirichenko, trust «Krymnaftohazrozvidka», association «Ukrnafta».
\end{abstract}

\title{
Аннотация
}

В статье на основе архивных материалов проведено исследование институичионального обеспечения, основных этапов и особенностей развития нефтегазового комплекса Крымской области в период после Второй 
мировой войны и в 1954 г. Целью статьи является комплексный анализ политики СССР в формировании институтов, осуществляющих освоение месторождений нефти $и$ газа в Крыму и основных направлений их деятельности, а также изменений в подходах к дальнейшему развитию нефтегазового комплекса Крымского полуострова после его включения в состав УССР в 1954 г. В результате проведенного исследования автором установлено, что структура институционального обеспечения нефтегазового комплекса Крымской области в период его пребывания в составе РСФСР не позволяла эффективно осваивать ресурсы полуострова. Развитие нефтегазовой отрасли в Крыму для Совета Министров РСФСР и профильных институтов Союзного Правительства не было приоритетным. Также, разведку перспективных нефтяных и газовых месторождений в Крыму было сосредоточено на Керченском полуострове. Передача Крымской области в состав УССР в 1954 г. закладывает возможности для изменения институциональной базы развития нефтегазового комплекса в Крыму, а также для постановки вопроса об освоении перспективных нефтегазоносных площадей на полуострове.

Ключевые слова: геофизические исследования в Крыму, Первый Секретарь Крымского обкома КПУ Д. Полянский, Первый Секретарь ЦК КПУ А. Кириченко, трест «Кримнефтегазразведка», объединение «Укрнафта».

\section{ДЖЕРЕЛА ТА ЛІТЕРАТУРА}

1. Атлас энергетических ресурсов СССР / Под. ред. А. Винтера, Г. Кржижановского. Москва-Ленинград : Главная редакция энергетической литературы, 1935. С. 15.

2. Карпов В. П. Нефть и газ в промышленной политике СССР (России). URL: https://m.cyberleninka.ru/article/n/neft-i-gaz-v-promyshlennoy-politikesssr-rossii

3. (В - П. С.) Совет Министров СССР (від - П. С.) Председателя Комитета государственной безопасности СССР при Совете Министров СССР И. Серова. 14 июня 1954 г. ЦДАГО України. Ф. 1. Оп. 24. Спр. 3725.

4. (В - П. С.) ЦК КП Украины тов. Кириченко А. И. (від - П. С.) Г. Есипенко. Принято по ВЧ 5.V-1954 г. ЦДАГО Украӥни. Ф. 1. Оп. 24. Спр. 3725.

5. (В - П. С.) Совет Министров УССР тов. Кальченко Н. Т., ЦК КП Украины тов. Подгорному Н. В. (від - П. С.) Ю. Дудина. Принято по ВЧ 17.VIII.1954 г. ЦДАГО Украӥни. Ф. 1. Оп. 24. Спр. 3725.

6. (В - П. С.) Совет Министров УССР товарищу Кальченко Н. Т., ЦК КП Украины товарищу Подгорному Н. В. (від - П. С.) Ю. Дудин. Сообщаю о ходе рассмотрения вопросов в Совете Министров СССР, министерствах и центральных ведомствах СССР по письмам Совета Министров УССР и ЦК КП Украины. Принято по ВЧ 21.VIII. 54 г. ЦДАГО Украйни. Ф. 1. Оп. 24. Спр. 3725. 
7. Председателю Совета Министров УССР товарищу Коротченко Д. А., Секретарю ЦК КП(б)У Мельникову Л. Г. (від - П. С.) Начальника Главного Управления строительства Южно-Украинского и СевероКрымского каналов «Укрводстроя» А. Бочкина и Начальника Сталинской ж. д. директор-полковника движения К. Коломийцева. 23 мая 1951 г. ЦДАВО Украӥни. Ф. Р-2. Оп. 8. Спр. 2414.

8. Решение геолого-технического совещания в гор. Феодосии, состоявшегося 17-20 марта 1954 г. «О направлениях и главных задачах геологопоисковых и разведочных работ на нефть и газ в Крымской области на 1954-1956 гг.» направлено в ЦК КП Украины Промышленный отдел, Крымский обком КП Украины Промышленный отдел; Крымский филиал АН СССР 27 марта 1954 г. ЦДАГО України. Ф. 1. Оп. 24. Спр. 3902.

9. Сводка о выполнении плана капитальных вложений организациями Крымской области за январь-декабрь 1953 года (данные текущей отчетности, по сметной стоимости в тыс. рублей). Статистические материалы, характеризующие развитие народного хазяйства и культуры Крымской области за ряд лет Секретарю Крымского обкома КП Украины тов. Полянському Д. С. (від - П. С.) начальника Статуправления Крымской области Н. Точеного. 18 марта 1954 г. ЦДАГО Украӥни. Ф. 1. Оп. 24. Спр. 3862.

10. Секретарю ЦК КП Украины тов. Кириченко А. И. (від - П. С.) Г. Есипенко. Принято по ВЧ 9.Х.1954 г. Сообщаю Вам о состоянии вопросов, поставленных ЦК КП Украины на рассмотрение в ЦК КПСС и союзных министерствах. ЦДАГО Украӥни. Ф. 1. Оп. 24. Спр. 2943.

11. Славкина М. В. Влияние отечественного нефтегазового комплекса на модернизационные процессы в СССР-России (1939-2008 гг.) : Автореф. дис... д-ра. ист. наук: 07.00.02 / Федеральное государственное бюджетное образовательное учреждение высшего профессионального образования «Московский государственный университет имени М. В. Ломоносова». Москва : 2013. $46 \mathrm{c.}$

12. Славкина М. Развитие нефтегазового комплекса СССР в 60-80-е гг.: большие победы и упущенные возможности. URL: http://hist.msu.ru/ Science/LMNS2002/24.htm

13. Справка о деятельности треста «Крымнефтегазразведка» Министерства нефтяной промышленности Центральному Комитету Коммунистической партии Украины (від - П. С.) Управляющего трестом «Крымнефтегазразведка». 5 мая 1954 г. ЦДАГО України. Ф. 1. Оп. 24. Спр. 3630.

14. Хромов Е. А. Проблемы выбора стратегии развития нефтегазового комплекса СССР в контексте ведомственных и региональных интересов в конце 1950-х - первой половине 1960-х гг. URL: http://brstu.ru/static/unit/ journal_2/docs/number-24/135-142.pdf 


\section{References}

1. Vinter, V \& Krzhizhanovskiy, G. (Eds.) (1935). Atlas energeticheskikh resursov SSSR. [Atlas of Energy Resources in USSR]. Moskva-Leningrad, Obyedinennoye nauchno-tekhnicheskoye izdatelstvo Glavnaya redaktsiya energeticheskoy literatury.

2. Karpov, V. P. Neft i gaz v promyshlennoy politike SSSR (Rossii) [Oil and gas in the industrial policy of the USSR (Russia)]. URL: https://m.cyberleninka.ru/ article/n/neft-i-gaz-v-promyshlennoy-politike-sssr-rossii

3. (V - P.S.) Sovet Ministrov SSSR (vid - P. S.) Predsedatelya Komiteta gosudarstvennoy bezopasnosti SSSR pri Sovete Ministrov SSSR I. Serova. 14 iyunya $1954 \mathrm{~g}$. [The Council of Ministers of the USSR from the Chairman of the Committee of State Security of the USSR at the Council of Ministers of the USSR I. Serov. June 14, 1954]. TsDAGO Ukrainy. F. 1. Op. 24. Spr. 3725.

4. (V - P. S.) TsK KP Ukrainy tov. Kirichenko A. I. (vid - P. S.) G. Esipenko. Prinyato po VCh 5.V-1954 g. [In the Central Committee of the Communist Party of Ukraine Comrade. Kirichenko AI from G. Esipenko. Adopted on 5 May 1954]. TsDAGO Ukrainy. F. 1. Op. 24. Spr. 3725.

5. (V - P. S.) Sovet Ministrov USSR tov. Kalchenko N. T., TsK KP Ukrainy tov. Podgornomu N. V. (vid - P. S.) Yu. Dudina. Prinyato po VCh 17.VIII.1954 g. [To the Council of Ministers of the Ukrainian SSR Comrade. Kalchenko N. T., Central Committee of the Ukrainian Communist Party Comrade. Podgorny NV from Yu. Dudin. Adopted on 17.VIII.1954]. TsDAGO Ukrainy. F. 1. Op. 24. Spr. 3725.

6. (V - P. S.) Sovet Ministrov USSR tovarishchu Kalchenko N. T., TsK KP Ukrainy tovarishchu Podgornomu N. V. (vid - P. S.) Yu. Dudin. Soobshchayu o khode rassmotreniya voprosov v Sovete Ministrov SSSR. ministerstvakh i tsentralnykh vedomstvakh SSSR po pismam Soveta Ministrov USSR i TsK KP Ukrainy. Prinyato po VCh 21.VIII.54 g. [To the Council of Ministers of the Ukrainian Soviet Socialist Republic, Comrade N. Kalchenko, and to the Central Committee of the Communist Party of Ukraine, Comrade Podgorny N. V. of $Y$. Dudin. I am reporting on the progress of the consideration of the issues in the USSR Council of Ministers, ministries and central departments of the USSR on letters from the Council of Ministers of the Ukrainian SSR and the Central Committee of the Ukrainian Communist Party. Accepted 21.VIII.54]. TsDAGO Ukrainy. F. 1. Op. 24. Spr. 3725.

7. Predsedatelyu Soveta Ministrov USSR tovarishchu Korotchenko D. A., Sekretaryu TsK KP(b)U Melnikovu L. G. (vid - P. S.) Nachalnika Glavnogo Upravleniya stroitelstva Yuzhno-Ukrainskogo i Severo-Krymskogo kanalov «Ukrvodstroya» A. Bochkina i Nachalnika Stalinskoy zh. d. direktorpolkovnika dvizheniya K. Kolomiytseva. 23 maya $1951 \mathrm{~g}$. [Sent to the Chairman of the Council of Ministers of the Ukrainian SSR Comrade D. Korotchenko and Secretary of the Central Committee of the Communist Party (Bolsheviks) of Ukraine Melnikov L. G. from the A. Bochkin, Head of the 
Main Directorate for the Construction of the South-Ukrainian and NorthCrimean Canals «Ukrvodstroi», and Colonel-Generall K. Kolomiytsev, Chief of the Stalin Railroad. May 23, 1951]. TsDAVO Ukrainy. F. P-2. Op. 8. Spr. 2414.

8. Resheniye geologo-tekhnicheskogo soveshchaniya $\mathrm{v}$ gor. Feodosii. sostoyavshegosya 17-20 marta $1954 \mathrm{~g}$. «O napravleniyakh i glavnykh zadachakh geologopoiskovykh $\mathrm{i}$ razvedochnykh rabot na neft $\mathrm{i}$ gaz $\mathrm{v}$ Krymskoy oblasti na 1954-1956 gg.» napravleno v TsK KP Ukrainy Promyshlennyy otdel. Krymskiy obkom KP Ukrainy Promyshlennyy otdel; Krymskiy filial AN SSSR 27 marta $1954 \mathrm{~g}$. [The decision of the geological meeting in the Feodosiya in March 17-20, 1954. "On the directions and main tasks of geological prospecting and exploration for oil and gas in the Crimean region for 1954-1956" was sent to the Industrial Department of Central Committee of the Ukrainian Communist Party and to the Industrial Department of Crimean Regional Committee of the Ukrainian Communist Party and Crimean branch of the USSR Academy of Sciences on March 27, 1954]. TsDAGO Ukrainy. F. 1. Op. 24. Spr. 3902.

9. Svodka o vypolnenii plana kapitalnykh vlozheniy organizatsiyami Krymskoy oblasti za yanvar-dekabr 1953 goda (dannyye tekushchey otchetnosti. po smetnoy stoimosti $\mathrm{v}$ tys. rubley). Statisticheskiye materialy kharakterizuyushchiye razvitiye narodnogo khazyaystva i kultury Krymskoy oblasti za ryad let Sekretaryu Krymskogo obkoma KP Ukrainy tov. Polyanskomu D. S. (vid - P. S.) nachalnika Statupravleniya Krymskoy oblasti N. Tochenogo. 18 marta $1954 \mathrm{~g}$. [Summary of the fulfillment of the capital investment plan by the organizations of the Crimean region for January-December 1953 (current reporting). Statistical materials characterizing the development of the national economy and culture of the Crimean region for a number of years to the Secretary of the Crimean Regional Committee of the Communist Party of Ukraine comrade. Polyanskiy D. S. from the head of the Department of Statistics of Crimean Region N. Tochenogo. March 18, 1954]. TsDAGO Ukrainy. F. 1. Op. 24. Spr. 3862.

10. Sekretaryu TsK KP Ukrainy tov. Kirichenko A. I. (vid - P. S.) G. Esipenko. Prinyato po VCh 9.X.1954 g. Soobshchayu Vam o sostoyanii voprosov. postavlennykh TsK KP Ukrainy na rassmotreniye $\mathrm{v}$ TsK KPSS i soyuznykh ministerstvakh. [Message to the Secretary of the Central Committee of the Communist Party of Ukraine Comrade. Kirichenko AI from G. Esipenko. Accepted 9.X.1954. I am informing you of the status of the questions put by the Central Committee of the Communist Party of Ukraine for consideration in the Central Committee of the CPSU and allied ministries]. TsDAGO Ukrainy. F. 1. Op. 24. Spr. 2943.

11. Slavkina, M. V. (2013). Vliyaniye otechestvennogo neftegazovogo kompleksa na modernizatsionnyye protsessy v SSSR-Rossii (1939-2008 gg.). [Influence 
of the domestic oil and gas complex on the modernization processes in the USSR-Russia (1939-2008)]. (Abstract of Doctor in history), Moscow.

12. Slavkina, M. Razvitiye neftegazovogo kompleksa SSSR v 60-80-e gg.: bolshiye pobedy i upushchennyye vozmozhnosti [The development of the oil and gas complex of the USSR in the 1960s-1980s: big victories and missed opportunities].URL: http://hist.msu.ru/Science/LMNS2002/24.htm

13. Spravka o deyatelnosti tresta «Krymneftegazrazvedka» Ministerstva neftyanoy promyshlennosti Tsentralnomu Komitetu Kommunisticheskoy partii Ukrainy (vid - P. S.) Upravlyayushchego trestom «Krymneftegazrazvedka». 5 maya 1954 g. [Information about the activities of the Crimean Neftegazrazvedka trust of the Ministry of Oil Industry to the Central Committee of the Communist Party of Ukraine for the Trust Manager of the Crimean Neftegazrazvedka. May 5, 1954]. TsDAGO Ukrainy. F. 1. Op. 24. Spr. 3630.

14. Khromov, E. A. Problemy vybora strategii razvitiya neftegazovogo kompleksa SSSR $\mathrm{v}$ kontekste vedomstvennykh i regionalnykh interesov $\mathrm{v}$ kontse $1950-\mathrm{kh}$ - pervoy polovine 1960-kh gg. [The problems of choosing a strategy for the development of the oil and gas complex of the USSR in the context of departmental and regional interests in the late 1950s and the first half of the 1960s.]. URL: http://brstu.ru/static/unit/journal_2/docs/number-24/135-142.pdf

УДК 314.748

\section{ДЕМОГРАФІЧНА СТРУКТУРА УКРАЇНСЬКОЇ ЕТНІЧНОЇ ГРУПИ У ЧЕСЬКІЙ РЕСПУБЛІЦ (1991-2011 роки)}

\section{Бойко Микола, Федоренко Евгеній}

У статті досліджується демографічна структура украӥнської етнічної групи на території Чеської Республіки протягом 1991-2011 рр. Порушується проблема відсутності у вітчизняній науці об'єктивної статистичної джерельної бази для оцінки міграційних втрат Украӥни, а також аналізуються перспективи залучення іноземних статистичних джерел для обрахунку масштабів еміграџї̈ населення України. Дослідження трунтується на підсумкових даних загальних переписів населення Чеської Республіки, що проводилися у 1991, 2001 та 2011 рр., які містять відомості щодо етнічних українців та русинів, котрі прожсивали на території країни. Розглянуто особливості статево-вікової структури украӥнської етнічної групи, а також особливості міграчійних потоків з України до Чехії у міжпереписні роки. Значну увагу приділено динаміці зміни вікової структури украӥнської етнічної групи протягом зазначеного періоду. Проаналізовано причини $і$ наслідки стрімкого демографічного омолодження української 